\title{
Spiroplasma ixodetis sp. nov., a New Species from Ixodes pacificus Ticks Collected in Oregon
}

\author{
JOSEPH G. TULLY, ${ }^{1 *}$ DAVID L. ROSE ${ }^{1} \dagger$ CONRAD E. YUNKER,${ }^{2} \ddagger$ PATRICIA CARLE, ${ }^{3}$ \\ JOSEPH M. BOVÉ, ${ }^{3}$ DAVID L. WILLIAMSON,${ }^{4}$ AND ROBERT F. WHITCOMB ${ }^{5}$ \\ Mycoplasma Section, Laboratory of Molecular Microbiology, National Institute of Allergy and Infectious Diseases, Frederick Cancer \\ Research Facility, Frederick, Maryland 21702 ${ }^{1}$; Rocky Mountain Laboratory, National Institute of Allergy and Infectious \\ Diseases, Hamilton, Montana 59840 ; Laboratoire de Biologie Cellulaire et Moléculaire, Institut Nationale de la \\ Recherche Agronomique, and Université Bordeaux II, 33883 Villenave d'Ornon, France ${ }^{3}$; Department \\ of Anatomical Sciences, State University of New York, Stony Brook, New York 11794; ; and \\ Insect Pathology Laboratory, Agricultural Research Service, U.S. Department of \\ Agriculture, Beltsville, Maryland $20705^{5}$
}

\begin{abstract}
Eight strains of mollicutes were isolated from pooled suspensions prepared from western black-legged ticks (Ixodes pacificus) collected in Oregon. Morphologic examination by electron and dark-field microscopic techniques showed that each strain consisted of a mixture of motile, tightly coiled helical cells, small coccoid cells with diameters ranging from 300 to $500 \mathrm{~nm}$, and pleomorphic, straight or branched filamentous forms. All cellular forms were surrounded by a single cytoplasmic membrane, and there was no evidence of a cell wall. The organisms were filterable and fastidious in their growth requirements. The optimum temperature for growth was $30^{\circ} \mathrm{C}$, but multiplication occurred at temperatures ranging from 23 to $32^{\circ} \mathrm{C}$. The strains catabolized glucose but did not hydrolyze arginine or urea. The genome size of strain $\mathrm{Y32}^{\mathrm{T}}(\mathrm{T}=$ type strain) was $2,220 \mathrm{kbp}$, and the DNA base composition (guanine-plus-cytosine content) of this organism was $25 \pm 1$ mol\%. The eight isolates were serologically related to each other but were not related to 37 other type or representative strains belonging to the genus Spiroplasma. Strain Y32 (= ATCC 33835) is the type strain of Spiroplasma ixodetis sp. nov.
\end{abstract}

Spiroplasmas (class Mollicutes) are helical, motile, wall-less prokaryotes that are associated with a variety of insects, other arthropods, and some plant hosts $(11,38,51)$. Although members of the genus Spiroplasma are usually commensal organisms in their arthropod hosts, several are pathogenic for insects and plants $(11,12,24,29,30)$.

The occurrence of spiroplasmas in hematophagous arthropods was first demonstrated in 1976 when two serologically distinct helical mollicutes (represented by strains SMCA and $277 \mathrm{~F}$ ) were identified in rabbit ticks (Haemaphysalis leporispalustris) (4, 41). Strain SMCA and two related strains were eventually characterized as Spiroplasma mirum (39). Strain $277 \mathrm{~F}$ is serologically and genomically related to Spiroplasma citri and was assigned to subgroup I-4 in an interim classification scheme for spiroplasmas $(21,36,44)$. Subsequently, spiroplasmas have been identified in blood-sucking members of the Diptera, including horseflies (Tabanus spp.), deerflies (Chrysops spp.), and mosquitoes (Adedes spp., Culex spp., etc.). The current status of these organisms has been summarized in several recent reviews or reports $(1,10,15,18,19,38,45)$.

We described additional isolations of tick-associated spiroplasmas in 1981 (37), including primary isolation of seven helical mollicutes from triturates of the western black-legged tick, Ixodes pacificus. While these organisms were isolated directly in SP-4 spiroplasma culture medium (43), a later report showed that most of the same isolates could be cultivated from stored triturates in several continuously maintained

\footnotetext{
* Corresponding author. Mailing address: Mycoplasma Section, BIdg. 550, NIAID, Frederick Cancer Res. Dev. Center, Frederick, MD 21702. Phone: (301) 846-1192. Fax: (301) 846-5165. Electronic mail address: JVT@CU.NIH.GOV.

$\dagger$ Present address: 8602 Cinnamon Creek, Apt. 209, San Antonio, TX 78240 .

$¥$ Present address: Veterinary Institute, Onderstepoort 0110 , Republic of South Africa.
}

cultured tick cell lines (53). An extensive serologic comparison of the strains isolated from $I$. pacificus showed that these organisms are closely related to each other but distinct from other previously described spiroplasmas. Strain $\mathrm{Y}^{2} 2^{\mathrm{T}}(\mathrm{T}=$ type strain) was selected as a representative of the group and was eventually designated a group VI strain in the interim classification system mentioned above $(21,36,48)$. Some general properties of group VI spiroplasmas have been described previously in other reports $(28,32,36,49)$.

In this paper, we describe additional taxonomic features of the isolates obtained from I. pacificus and propose that they should be assigned to a new species in the genus Spiroplasma.

\section{MATERIALS AND METHODS}

Spiroplasma strains. Approximately 600 adult $I$. pacificus ticks that had been collected in southern Oregon between December 1979 and July 1980 were divided into about 30 pools (representing male, female, and mixed-sex collections). The techniques used to prepare whole-tick suspensions for culture and the media used for primary isolation have been described previously (37). Seven of the pools (designated pools Y29, Y30, Y32, Y39, Y43, Y49, and Y107) yielded spiroplasma isolates, usually after incubation for 20 to 25 days at $30^{\circ} \mathrm{C}$. The eighth pool (Y85) was positive only after cultures were incubated for 2 months and three or four blind passages. Isolates were obtained from both male and female tick pools, and all spiroplasmas isolated in culture were purified by conventional triple-cloning techniques (33). The strain selected as the representative of the group, strain $\mathrm{Y} 32^{\mathrm{T}}$, has been deposited in the American Type Culture Collection as strain ATCC $33835^{\mathrm{T}}$.

The 37 other spiroplasmas used in our serologic analysis of $\mathrm{Y}_{32}{ }^{\mathrm{T}}$, including members of previously described Spiroplasma species or currently recognized serogroups, are listed in Table 1 . These strains were maintained as individual reference collections in the Beltsville, Frederick, or Stony Brook laboratory.

Culture medium and cultivation techniques. All primary isolations of spiroplasmas from ixodid ticks were made in SP-4 broth $(43)$ at $30^{\circ} \mathrm{C}$, and most characterization tests also were performed in this medium. This broth formulation also contained $500 \mathrm{U}$ of penicillin per ml. Solid SP-4 medium was prepared by adding $2.25 \%$ Noble agar (so-called "hard agar"); we used this formulation rather than the conventional $0.8 \%$ agar formulation used for nonhelical mollicutes. Agar plates were incubated at $30^{\circ} \mathrm{C}$ either under aerobic conditions or in jars containing an anaerobic hydrogen GasPak system (BBL Microbiology Systems, Cockeysville, Md.). 
TABLE 1. Spiroplasma strains and antisera used in our serologic analysis of strain $\mathrm{Y} 32^{\mathrm{T} a}$

\begin{tabular}{|c|c|c|c|c|}
\hline Group & Species and/or strain & $\begin{array}{c}\text { Size of } \\
\text { GI zone } \\
(\mathrm{mm})^{b}\end{array}$ & $\underset{\text { titer }^{c}}{D F}$ & MI titer ${ }^{d}$ \\
\hline $\mathrm{I}-1$ & S. citri Maroc R8A2 ${ }^{\mathrm{T}}$ & 16 & 2,560 & $>117,000$ \\
\hline $\mathrm{I}-2$ & S. melliferum $\mathrm{BC}-3^{\mathrm{T}}$ & 12 & 10,240 & $>117,000$ \\
\hline I-3 & S. kunkelii $\mathrm{E} 275^{\mathrm{T}}$ & 18 & 20,480 & 39,000 \\
\hline I-4 & $277 \mathrm{~F}$ & 14 & 5,120 & 39,000 \\
\hline I-5 & LB-12 & 18 & 5,120 & $>117,000$ \\
\hline 1-6 & S. insolitum M55 ${ }^{\mathrm{T}}$ & 13 & 1,280 & 13,000 \\
\hline I-7 & N525 & 11 & 10,240 & 39,000 \\
\hline I-8 & S. phoeniceum ${ }^{T}$ & 17 & 10,240 & $>117,000$ \\
\hline II & DW1 & $\mathrm{ND}^{e}$ & 2,560 & ND \\
\hline III & S. floricola $\mathrm{OBMG}$ & 6 & 10,240 & 13,000 \\
\hline IV & S. apis $\mathrm{B} 31^{\mathrm{T}}$ & 5 & 1,280 & 13,000 \\
\hline V & S. mirum $\mathrm{SMCA}^{\mathrm{T}}$ & 13 & 5,120 & 13,000 \\
\hline VI & Y32 & 16 & 2,560 & 4,374 \\
\hline VII & S. monobiae $\mathrm{MQ}-1^{\mathrm{T}}$ & 6 & 1,280 & $>117,000$ \\
\hline VIII & EA-1 & 10 & 1,280 & 39,000 \\
\hline IX & S. clarkii $\mathrm{CN}-5^{\mathrm{T}}$ & 10 & 640 & 4,374 \\
\hline $\mathrm{X}$ & S. culicicola AES-1 ${ }^{\mathrm{T}}$ & 8 & 640 & 4,374 \\
\hline XI & MQ-4 & 5 & 640 & 4,374 \\
\hline XII & DU-1 & 5 & 2,560 & 13,000 \\
\hline XIII & S. sabaudiense Ar- $1343^{\mathrm{T}}$ & 8 & 2,560 & 13,000 \\
\hline XIV & EC-1 & 5 & 1,280 & 13,000 \\
\hline$X V$ & $\mathrm{I}-25$ & 8 & 1,280 & $>117,000$ \\
\hline XVI & S. cantharicola $\mathrm{CC}-1^{\mathrm{T}}$ & 5 & 1,280 & 39,000 \\
\hline XVII & DF-1 & 10 & 5,120 & 39,000 \\
\hline XVIII & $\mathrm{TN}-1$ & 6 & 1,280 & $>117,000$ \\
\hline XIX & PUP-1 & 14 & 5,120 & 13,000 \\
\hline $\mathrm{XX}$ & LD-1 & ND & 5,120 & ND \\
\hline XXI & W115 & 15 & 1,280 & 4,374 \\
\hline XXII & S. taiwanense CT- $1^{\mathrm{T}}$ & 8 & 1,280 & 13,000 \\
\hline XXIII & TG-1 & 7 & 2,560 & 39,000 \\
\hline XXIV & S. chinen & 4 & 640 & 1,458 \\
\hline Ungro & 1 (horsefly) & 8 & 5,120 & 39,000 \\
\hline Ungrouped & BIUS-1 (Bidens flowers) & 7 & 10,240 & 13,000 \\
\hline Ungrouped & TABS-2 (horsefly) & 7 & 640 & 39,000 \\
\hline Ungrouped & TALS-2 (horsefly) & 7 & 320 & 1,458 \\
\hline Ungrouped & PLHS-1 (scorpion fly) & 11 & 2,560 & 4,374 \\
\hline Ungrouped & TAUS-1 (horsefly) & 7 & 5,120 & 13,000 \\
\hline Ungrouped & PALS-1 (dragonfly) & 7 & 1,280 & 4,374 \\
\hline
\end{tabular}

${ }^{a}$ Strain $\mathrm{Y} 32^{\mathrm{T}}$ antigen was used in three serologic tests along with antiserum to each of the spiroplasma strains examined. Reciprocal tests against $\mathrm{Y} 32^{\mathrm{T}}$ antiserum were also performed with each spiroplasma strain. We found that the group VI isolates were related, but strain $\mathrm{Y}^{2} 2^{\mathrm{T}}$ was not serologically related to the strains belonging to groups I through V and VII through XXIV or to representatives of ungrouped spiroplasma clusters.

${ }^{b}$ Zones of homologous GI obtained with type-specific antisera to the organisms tested. We measured zones of GI around antiserum-saturated discs on agar plates containing colony growth. In homologous tests $\mathrm{Y}^{3} 2^{\mathrm{T}}$ antigen produced a 16 -mm zone of inhibition, while all other antisera produced zones that were 2 $\mathrm{mm}$ or less wide.

"Homologous DF test titers obtained with type-specific antisera to the organisms tested. We determined the reciprocal of the highest dilution of antiserum that deformed at least one-half of the spiroplasmas. $\mathrm{Y}^{3} 2^{\mathrm{T}}$ antigen tested against homologous antiserum produced a DF titer of 1:2,560, while $\mathrm{Y} 32^{\mathrm{T}}$ tests performed with all other antisera resulted in titers of 1:20 or less.

${ }^{d}$ Homologous MI test titers obtained with type-specific antisera to the organisms tested. We determined the reciprocal of the highest dilution of antiserum that resulted in GI of a standard broth inoculum. $\mathrm{Y}^{2}{ }^{\mathrm{T}}$ antigen tested against homologous antiserum produced an MI titer of 1:4,354, and $\mathrm{Y}^{\mathrm{T}}$ antigen tested against all other antisera produced titers of 1:18 or less.

${ }^{e} \mathrm{ND}$, not done.

The temperature requirements for growth of the eight strains were determined by incubating broth cultures at various temperatures $(10,18,23,30,32$, and $37^{\circ} \mathrm{C}$ ), and growth was recorded as the number of color-changing units (CCU) per milliliter observed over a 3-week period. Early passages of the eight strains were also grown in SP-4 broth medium lacking antibiotics for at least five consecutive passages. After each passage, the strains were plated onto conven- tional blood agar plates and examined for evidence of reversion to bacterial-type colonies.

Tests for biological and biochemical properties. The procedures used to determine glucose fermentation (2), hydrolysis of arginine and urea (2), filtration characteristics in SP-4 broth (33), and hemadsorption (17) have been described previously.

Morphological studies. All eight spiroplasma isolates obtained from ticks were examined by dark-field microscopy (magnification, $\times 1,250$ ), using SP-4 broth cultures that varied from the early logarithmic growth phase to the late stationary phase. Strain $\mathrm{Y}^{3} 2^{\mathrm{T}}$ was studied electron microscopically by both negative staining and thin-section techniques. The procedures used for each of these techniques have been described previously (38).

Sterol requirement. Strain $\mathrm{Y}^{2} 2^{\mathrm{T}}$ and other isolates obtained from ixodid ticks in this study had rather fastidious growth requirements, and little growth occurred in most medium formulations containing reduced amounts of serum. These circumstances made it difficult to measure sterol requirements by the conventional broth-protein yield method (26). However, we used a technique used previously for other fastidious spiroplasmas $(S$. mirum) (39). In this modified technique, growth responses (in CCU per milliliter) were measured in base serum-free broth alone and in base medium containing various quantities of fetal bovine serum or cholesterol. In addition, we also examined the susceptibility of ixodid spiroplasmas to $1.5 \%$ digitonin, which provided an indirect measurement of sterol requirements (16).

Serological tests. Antiserum to strain $\mathrm{Y} 32^{\mathrm{T}}$ was prepared in rabbits by using previously described techniques (31). Disc growth inhibition (GI) tests in which we used $\mathrm{Y}^{2} 2^{\mathrm{T}}$ antiserum and previously described Spiroplasma species or group representatives were carried out as previously described $(13,47)$, using SP-4 hard agar. The procedures used for reciprocal testing of $\mathrm{Y}^{3} 2^{\mathrm{T}}$ antigen and antisera in spiroplasma metabolism inhibition (MI) and deformation (DF) tests have also been described previously $(50,52)$. The addition of complement $(10 \%$ guinea pig serum) in the MI test was found to be inhibitory to all of the ixodid spiroplasma strains examined (49); therefore, complement was omitted from all MI tests in which these organisms were used.

Genomic analysis. Genome size was determined by pulsed-field gel electrophoresis of undigested linear genomic molecules and from the summed sizes of restricted DNA fragments. Genomic DNA embedded in LMP agarose (Geneline-Beckman, Palo Alto, Calif.) was prepared as described previously $(6,7,25)$, except that the cellular pellet was resuspended in STE $(100 \mathrm{mM} \mathrm{NaCl}, 10 \mathrm{mM}$ Tris-HCl [pH 7.5], 1 mM EDTA). Restriction enzymes SmaI, ApaI, and SalI were used as recommended by the manufacturer, and digestion preparations were incubated overnight. The restriction fragments were separated on a $1 \% \mathrm{LE}$ agarose gel by using a transverse alternating field electrophoresis apparatus (Geneline-Beckman). The sizes of all separated fragments were evaluated by comparison with yeast chromosomal DNA fragments (Bio-Rad, Richmond, Calif.), which varied in size from 215 to $2,200 \mathrm{kbp}$, and with lambda phage DNA concatemers (New England Biolabs, Beverly, Mass.)

The guanine-plus-cytosine $(\mathrm{G}+\mathrm{C})$ content of purified DNA was determined by buoyant density, melting temperature, and high-performance liquid chromatography (HPLC) techniques (9). The methods used for extraction and purification of DNA from mollicutes have been described previously (8). Purified DNA from $S$. citri (base composition, $26 \pm 1 \mathrm{~mol} \%$ ) was used as a control.

\section{RESULTS AND DISCUSSION}

Cultural and morphologic properties. All eight ixodid isolates grew in SP-4 broth but required prolonged incubation (20 to 25 days) for primary isolation. Following cloning and repeated broth passage, most strains began to exhibit evidence of carbohydrate fermentation after incubation at $30^{\circ} \mathrm{C}$ for 5 to 10 days. In early passages, little growth occurred in most other medium formulations used for spiroplasmas or mycoplasmas. After laboratory cultivation for 10 to 20 passages, some strains were able to grow on spiroplasma medium M1A or M1D (43). The organisms were very sensitive to changes in the quality of the fresh yeast extract or fetal bovine serum components in SP-4 broth, and strain Y32 ${ }^{\mathrm{T}}$ eventually became a useful test organism for quality control of SP-4 medium. Likewise, reductions in the serum content severely reduced the amount of growth. Growth also occurred within a very narrow temperature range $\left(23\right.$ to $\left.32^{\circ} \mathrm{C}\right)$. After 21 days of incubation, optimum growth was observed at either $30^{\circ} \mathrm{C}\left(10^{8} \mathrm{CCU} / \mathrm{ml}\right)$ or $23^{\circ} \mathrm{C}\left(10^{7}\right.$ $\mathrm{CCU} / \mathrm{ml})$, some growth was observed at $32^{\circ} \mathrm{C}\left(10^{4} \mathrm{CCU} / \mathrm{ml}\right)$, and no growth was apparent in cultures incubated at 10,18 , or $37^{\circ} \mathrm{C}$. Agar colonies of the ixodid spiroplasmas were classical fried egg colonies on SP-4 hard agar when the organisms were incubated at $30^{\circ} \mathrm{C}$ under aerobic conditions (Fig. 1A). How- 

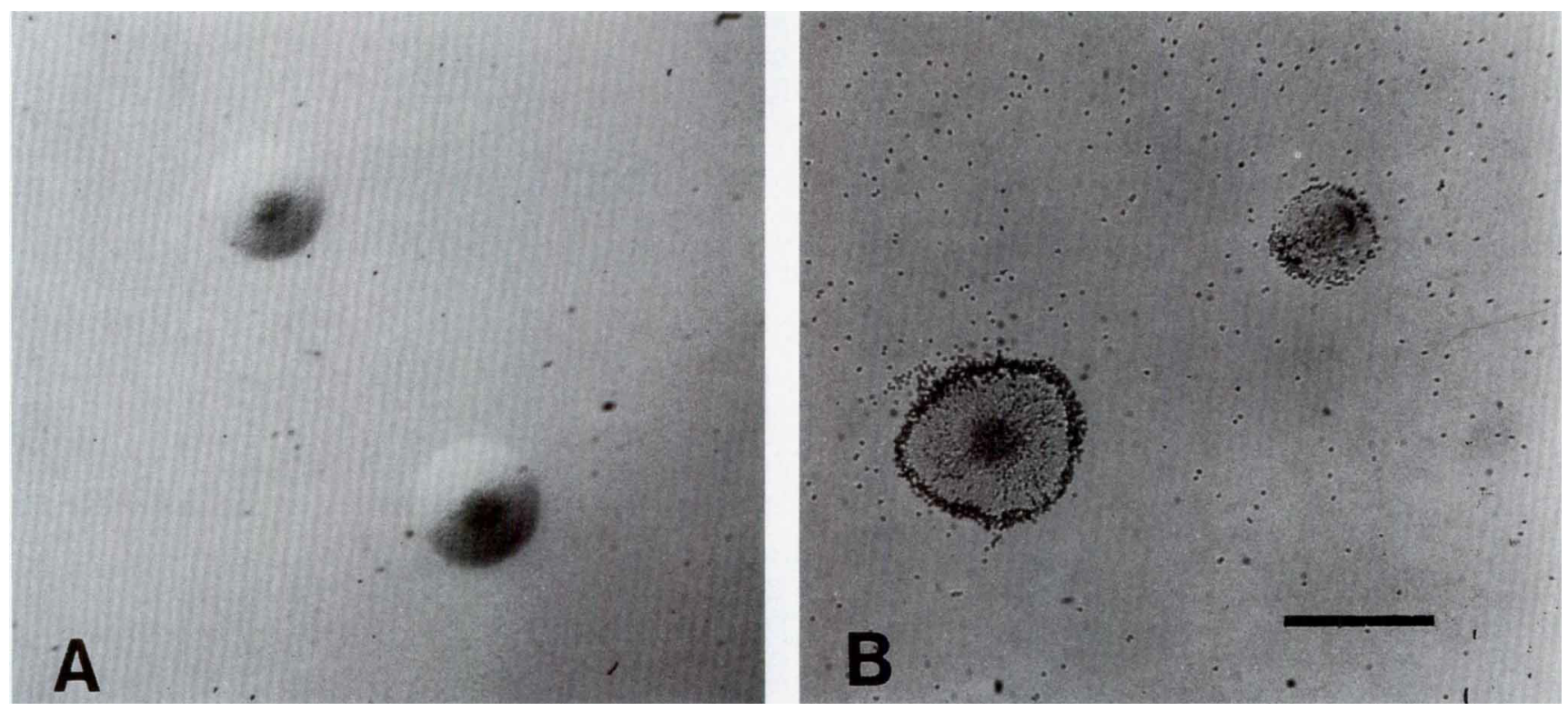

FIG. 1. Colony morphology and hemadsorption activity of spiroplasma strain $\mathrm{Y} 32^{\mathrm{T}}$. (A) Strain $\mathrm{Y} 32^{\mathrm{T}}$ grown for 10 days on SP-4 hard agar at $30^{\circ} \mathrm{C}$ under aerobic conditions. (B) Strain $\mathrm{Y}^{\mathrm{T}} 2^{\mathrm{T}}$ agar colonies exhibiting positive hemadsorption of guinea pig erythrocytes. Bar $=100 \mu \mathrm{m}$.

ever, a period of 10 to 14 days of incubation was usually required for satisfactory colony growth. No evidence of bacterial growth occurred on blood agar plates when spiroplasma isolates grown for five or more passages in SP-4 broth lacking antibiotics were plated onto this medium.

Dark-field microscopic examination of broth cultures of the eight ixodid isolates at various phases of growth revealed a unique mixture of predominantly filamentous forms, some of which were straight and some of which were branched or had Y-shaped elements. A few helical and coccoid forms were usually found in each preparation, but the number of helices was always much less than the number of other morphologic forms. In older cultures, we observed large cellular clumps, each of which contained numerous motile filaments at the periphery of the clump. Most of the motility was expressed as flexional but not translational movement. In several instances, we observed peripheral filaments that changed rapidly from helical cells to relaxed straight filaments.

Fixed cells were examined by negative staining and electron microscopy, and these preparations showed that many small cells were tightly coiled helical filaments (Fig. 2A). It seemed likely that these small helical cells were interpreted as small straight filaments when they were examined by dark-field microscopy at a lower magnification. Thin sections of fixed cells revealed primarily coccoid cells (diameter, 300 to $500 \mathrm{~nm}$ ) or curved forms (37) (Fig. 2B). All cells observed by electron microscopy were surrounded only by a single membrane and lacked cell walls (37). However, some sectioned cells also had a unique 8-nm-thick structure that was under the plasmalemma in the cell (Fig. 2B); the function of this structure is not known. Like many other Spiroplasma species and unclassified strains $(38,51)$, intracellular virus-like particles were observed in strain $\mathrm{Y}^{\mathrm{T}}$ (Fig. 2C).

Sterol requirement. The requirement for cholesterol or serum by strain $\mathrm{Y} 32^{\mathbf{T}}$ was established by a modified sterol test (Table 2). Growth enhancement was apparent when 10 to 20 $\mu \mathrm{g}$ of cholesterol per $\mathrm{ml}$ was incorporated into the serum-free base medium or when 5 to $15 \%$ fetal bovine serum was added. The inhibition zone for digitonin susceptibility was $9 \mathrm{~mm}$ wide, which indirectly indicated that sterol was required $(16,34)$. In addition, strain $\mathrm{Y} 32^{\mathrm{T}}$ was also included in a recently described study in which Rose et al. determined the requirements of mollicutes for serum or polyoxyethylene sorbitan (Tween 80) (27). In this study, sustained growth of $\mathrm{Y}^{\mathrm{T}} 2^{\mathrm{T}}$ through 23 serial dilutions occurred only in media containing serum.

Biochemical and biological properties. All eight ixodid isolates catabolized glucose. Repeated attempts to demonstrate arginine hydrolysis, even in the presence of glucose, were uniformly negative. Likewise, tests for urea hydrolysis were negative. Although colonies of all strains hemadsorbed guinea pig erythrocytes (Fig. 1B), we did not observe hemadsorption with sheep, bovine, rat, rabbit, monkey, or human type $\mathrm{O}$ erythrocytes. Unfiltered broth cultures of $\mathrm{Y} 32^{\mathrm{T}}$ had a titer of $10^{8} \mathrm{CCU} / \mathrm{ml}$. Filtration through membranes with average pore diameters of $450,300,220$, and $100 \mathrm{~nm}$ yielded titers of $10^{7}$, $10^{7}, 10^{4}$, and $10^{1} \mathrm{CCU} / \mathrm{ml}$, respectively.

Serological tests. GI, DF, and MI tests were performed with the eight ixodid spiroplasmas and type-specific antiserum to strain $Y 32^{\mathrm{T}}$ prepared in rabbits. The results of these tests (data not shown) confirmed that all eight ixodid tick-derived strains were closely related. We also performed reciprocal GI, MI, and DF tests, in which we used $\mathrm{Y}^{2}{ }^{\mathbf{T}}$ antigen and antisera versus many antigens and type-specific antisera to previously described Spiroplasma species (designated group representatives) or currently ungrouped strains (Table 1). Table 1 shows the homologous values obtained with the various type-specific antisera in each of the serologic tests, which were determined to establish the potency of the test sera. In heterologous tests of $\mathrm{Y}_{32}^{\mathrm{T}}$ antigen or antisera versus other Spiroplasma species, groups, or putative species, GI zones of $2 \mathrm{~mm}$ or less, DF titers of 1:20 or less, and MI titers of 1:18 or less were observed. Our findings clearly established that strain $\mathrm{Y}^{2} 2^{\mathrm{T}}$ is not significantly serologically related to previously described Spiroplasma species or groups.

Genome size and DNA base composition. DNA renaturation kinetics were used in early attempts to determine the genome sizes of the ixodid spiroplasmas. The results of such tests were difficult to interpret since at least three renaturation curves 

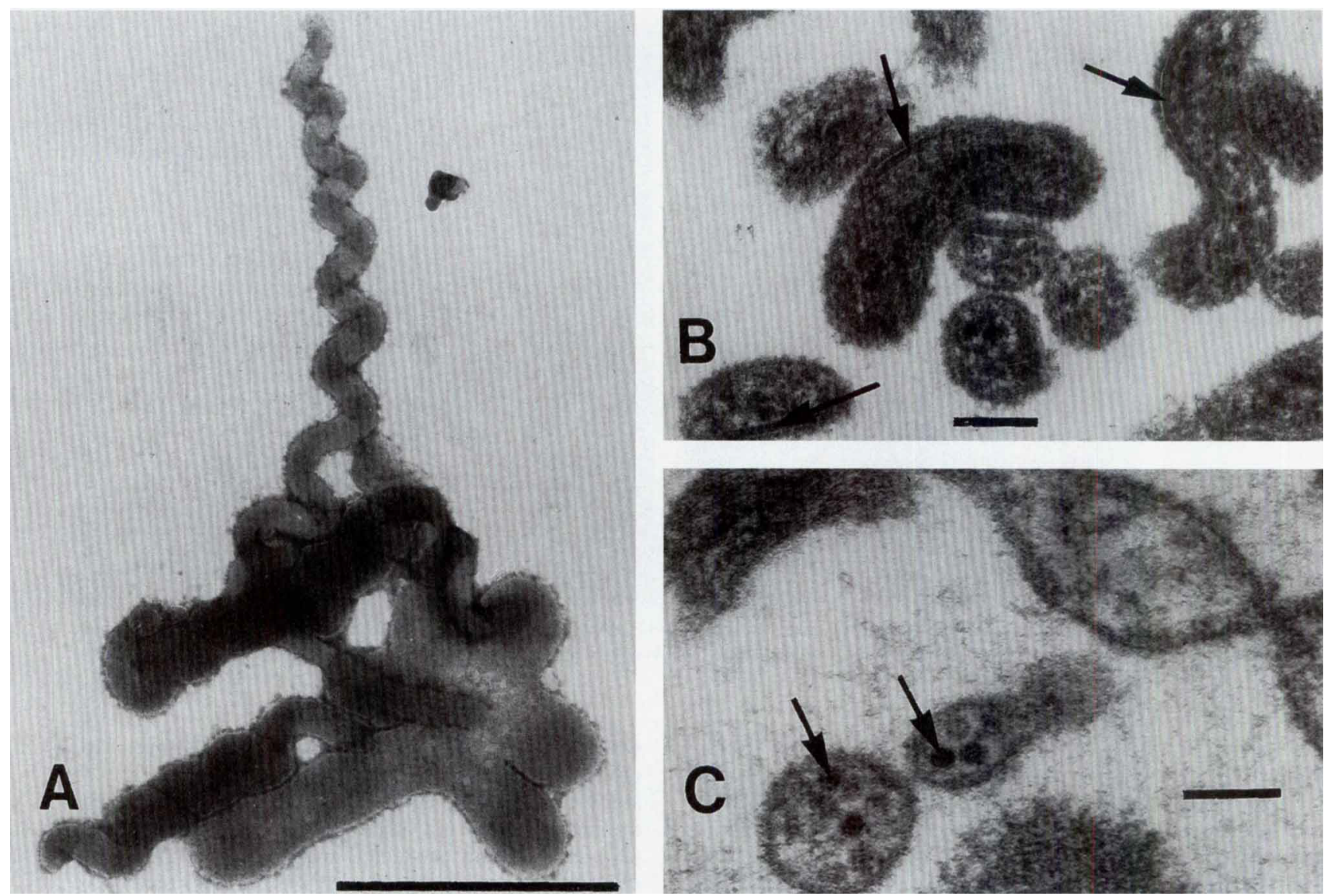

FIG. 2. Ultrastructural morphology of strain $\mathrm{Y} 32^{\mathrm{T}}$. (A) Negatively stained spiroplasma strain $\mathrm{Y} 32^{\mathrm{T}}$ cells, showing that the cells are pleomorphic. Bar $=1 \mu \mathrm{m}$. (B) Thin section of a strain $\mathrm{Y} 32^{\mathrm{T}}$ cell pellet. The arrows indicate the 8-nm-thick subplasmalemmal structure that appears to be limited to one side of the organism. Bar $=100 \mathrm{~nm}$. (C) Thin section of a strain $\mathrm{Y} 32^{\mathrm{T}}$ cell pellet. The arrows indicate intracellular virus-like particles. Bar $=100 \mathrm{~nm}$.

were observed consistently when purified DNA from each of the organisms was analyzed. Pulsed-field gel electrophoresis provided a much more accurate procedure for measuring the sizes of large genomes. Undigested linear genomic material from $\mathrm{Y} 32^{\mathrm{T}}$ was found to be $2,220 \mathrm{kbp}$ long. Genome sizes of $2,225,2,240$, and $2,265 \mathrm{kbp}$ were obtained for strain $\mathrm{Y} 32^{\mathrm{T}}$ when

TABLE 2. Sterol requirement of spiroplasma strain $\mathrm{Y} 32^{\mathrm{T}}$

\begin{tabular}{lcccc}
\hline \multirow{2}{*}{$\begin{array}{c}\text { Addition to base } \\
\text { medium }\end{array}$} & Concn & \multicolumn{3}{c}{$\begin{array}{c}\text { No. of organisms (CCU/ml) after } \\
\text { incubation at } 30^{\circ} \mathrm{C} \text { for: }\end{array}$} \\
\cline { 2 - 5 } & & 7 days & 14 days & 21 days \\
\hline None $^{a}$ & & $10^{1}$ & $10^{1}$ & $10^{1}$ \\
None $^{b}$ & $1 \mu \mathrm{g} / \mathrm{ml}$ & $10^{1}$ & $10^{1}$ & $10^{1}$ \\
Cholesterol $^{c}$ & $5 \mu \mathrm{g} / \mathrm{ml}$ & $10^{1}$ & $10^{1}$ & $10^{1}$ \\
& $10 \mu \mathrm{g} / \mathrm{ml}$ & $10^{1}$ & $10^{3}$ & $10^{1}$ \\
& $20 \mu \mathrm{g} / \mathrm{ml}$ & $10^{1}$ & $10^{3}$ & $10^{3}$ \\
& $0.5 \%$ & $10^{1}$ & $10^{2}$ & $10^{2}$ \\
Fetal bovine serum $^{c}$ & $5 \%$ & $10^{1}$ & $10^{3}$ & $10^{3}$ \\
& $10 \%$ & $10^{1}$ & $10^{3}$ & $10^{5}$ \\
& $15 \%$ & $10^{2}$ & $10^{3}$ & $10^{5}$ \\
& $20 \%$ & $10^{2}$ & $10^{2}$ & $10^{3}$ \\
\hline
\end{tabular}

\footnotetext{
${ }^{a}$ Serum-free base medium alone.

${ }^{b}$ Base medium supplemented with $0.5 \%$ fatty acid-poor albumin, $0.01 \%$ Tween 80 , and $10 \mu \mathrm{g}$ of palmitic acid per $\mathrm{ml}$.

${ }^{c}$ All medium preparations contained the supplements described in footnote $b$.
}

we added the sizes of the restriction fragments obtained after digestion with enzymes $S m a \mathrm{I}, A p a \mathrm{I}$, and SalI, respectively. Thus, the genome of $\mathrm{Y}_{3} 2^{\mathrm{T}}$ is close to $2,220 \mathrm{kbp}$ long; this is the largest genome size that has been obtained so far for any mollicute (6). The DNA base composition values determined by the three techniques mentioned above indicated that the $\mathrm{G}+\mathrm{C}$ content was $25 \pm 1 \mathrm{~mol} \%$.

Although strain $\mathrm{Y} 32^{\mathrm{T}}$ and its allies appeared to be true spiroplasmas, the occurrence of many nonhelical forms in young broth cultures and the unusual genome size raised the possibility that these organisms might belong to a new taxon. However, information obtained in a recent phylogenetic study of 45 mollicutes supported the hypothesis that $\mathrm{Y}^{2} 2^{\mathbf{T}}$ and other members of the genus Spiroplasma are related (42). In a comparison of $16 \mathrm{~S}$ rRNA sequences, strain $\mathrm{Y}^{\mathrm{T}} 2^{\mathrm{T}}$ clustered with a group of nine other spiroplasmas.

Habitat. The eight serologically related spiroplasmas isolated from I. pacificus are the only helical mollicutes that have been found in ticks other than the mollicutes associated with the rabbit tick (H. leporispalustris). A limited number of other ticks, including members of both the Ixodidae (hard ticks) and the Argasidae (soft ticks), have been examined for spiroplasmas, with negative results (40). In general, the real extent of spiroplasma occurrence in ticks is unknown, since few epidemiologic surveys have been performed. I. pacificus is an important pest of humans, domestic stock, and game animals. This species occurs along the western seaboard of North 
America from British Columbia to Mexico, usually west of the Cascade and Sierra Nevada mountain ranges, and has been found in several sites west of the Wasatch Range in Utah (14).

At least 55 vertebrate species have been reported to be hosts for adult, larval, or nymphal forms of I. pacificus (3); this tick has been recovered most frequently from the western fence lizard (Sceloporus occidentalis) $(22,23)$, other reptiles, and rodent or avian species. The optimum growth temperature for the $\mathrm{Y} 32^{\mathrm{T}}$ group of spiroplasmas $\left(30\right.$ to $\left.32^{\circ} \mathrm{C}\right)$ suggests that reptiles or other poikilotherms might be more important reservoirs of the organisms than mammals or avian hosts. It is not known whether spiroplasma occurrence is related to the developmental stages of the ticks (i.e., transovarial and transtadial transmission) or whether vertebrates play an essential role in maintaining spiroplasmas in ticks. Thus, the spiroplasmas in I. pacificus ticks might well represent primary spiroplasma infections in reptile, rodent, or avian hosts rather than natural arthropod infections. It should also be noted that $I$. pacificus is one of the principal reservoirs and transmission vectors for Borrelia burgdorferi (5), an important disease agent in humans. Since Borrelia and Spiroplasma species are not easily differentiated by dark-field microscopy, assessments to determine the occurrence of either species in Ixodes tick suspensions should not be based on direct morphologic observations. However, the presence of spiroplasmas in I. pacificus ticks, which have been described as "vicious human-biters" (23), and in a variety of blood-feeding tabanids, deerflies, and mosquitoes suggests that these organisms may have the potential to be agents of human disease. The apparent inability of the spiroplasmas described in this paper to grow well at $37^{\circ} \mathrm{C}$ (in contrast to $S$. mirum strains [39]) argues against this possibility. However, descriptions of the biologic and serologic properties of microbial agents such as the $\mathrm{Y} 32^{\mathrm{T}}$ group may provide the basis for a useful detection system if in the future tick-derived diseases of unknown etiology appear.

The properties of strain $\mathrm{Y}^{3} 2^{\mathrm{T}}$ described in this paper fulfill the criteria for species descriptions of members of the class Mollicutes $(20,35)$. The cells of this organism lack a cell wall, are filterable, fail to revert to walled bacteria when they are grown in antibiotic media, are resistant to penicillin, and produce typical fried egg colonies on solid media. The growth requirement for sterol or serum, the optimum growth temperature of $30^{\circ} \mathrm{C}$, helicity, and the close phylogenetic relationships to other spiroplasmas (as determined by 16S rRNA comparisons) place this organism in the order Entomoplasmatales, the family Spiroplasmataceae, and the genus Spiroplasma $(35,38$, 46). The lack of serological relatedness of strain $\mathrm{Y}^{3} 2^{\mathrm{T}}$ to other Spiroplasma species demonstrates that this strain is a member of a previously unrecognized species in the genus. We propose the name Spiroplasma ixodetis for strain $\mathrm{Y}^{2}{ }^{\mathrm{T}}$.

The taxonomic description below summarizes the properties of the species.

Description of Spiroplasma ixodetis. Spiroplasma ixodetis (ix.o.de'tis M.L. gen. n. ixodetis, of Ixodes, the genus name of $I$. pacificus ticks, from which the organism was first isolated). Cells consist of various mixtures of coccoid forms (diameter, 300 to $500 \mathrm{~nm}$ ), straight and branched filamentous cells, and helical organisms. Cells lack a cell wall. Motile. Colonies on solid medium containing $2.25 \%$ Noble agar usually have the appearance of fried eggs. Chemoorganotroph. Acid is produced from glucose. Does not hydrolyze arginine or urea. Agar colonies hemadsorb guinea pig erythrocytes but not erythrocytes of other mammalian species.

Cholesterol or serum is required for growth.

The temperature range for growth is 23 to $32^{\circ} \mathrm{C}$; optimum growth occurs at $30^{\circ} \mathrm{C}$.
Serologically distinct from previously described Spiroplasma species.

Isolated from macerated tissue suspensions prepared from pooled adult $I$. pacificus ticks (Ixodidae) collected in Oregon.

Pathogenicity for plants or insects has not been determined. Organisms exhibit growth and cytadherence to various tick and insect cells in culture, without obvious cytopathogenic effects.

The average genome size is $2,220 \mathrm{kbp}$. The average $\mathrm{G}+\mathrm{C}$ content of the DNA is $25.0 \mathrm{~mol} \%$, as determined by buoyant density, melting temperature, and HPLC techniques.

The type strain is Y32 (= ATCC 33835).

\section{ACKNOWLEDGMENTS}

We thank R. A. Gresbrink of the Oregon State Health Division, Portland, for his efforts in tick collection and Mark Aronoff, Department of Linguistics, State University of New York, Stony Brook, for his assistance in the Latin derivation.

\section{REFERENCES}

1. Abalain-Colloc, M. L., D. L. Williamson, P. Carle, J. H. Abalain, F. Bonnet, J. G. Tully, M. Konai, R. F. Whitcomb, J. M. Bové, and C. Chastel. 1993. Division of group XVI spiroplasmas into subgroups. Int. J. Syst. Bacteriol. 43:342-346.

2. Aluotto, B. B., R. G. Wittler, C. O. Williams, and J. E. Faber. 1970. Standardized bacteriologic techniques for characterization of Mycoplasma species. Int. J. Syst. Bacteriol. 20:35-58.

3. Arthur, D. R., and K. R. Snow. 1968. Lxodes pacificus Cooley and Kohls, 1943: its life-history and occurrence. Parasitology 58:893-906.

4. Brinton, L. P., and W. Burgdorfer. 1976. Cellular and subcellular organization of the $277 \mathrm{~F}$ agent, a spiroplasma from the rabbit tick Haemaphysalis leporispalustris (Acari: Ixodidae). Int. J. Syst. Bacteriol. 26:554-560.

5. Burgdorfer, W., R. S. Lane, A. G. Barbour, R. A. Gresbrink, and J. R. Anderson. 1985. The western black-legged tick, Lxodes pacificus: a vector of Borrelia burgdorferi. Am. J. Trop. Med. Hyg. 34:925-930.

6. Carle, P., F. Laigret, J. M. Bové, and J. G. Tully. Heterogeneity of genome sizes within the genus Spiroplasma. Submitted for publication.

7. Carle, P., D. L. Rose, J. G. Tully, and J. M. Bové. 1992. The genome size of spiroplasmas and other mollicutes. IOM Lett. 2:263.

8. Carle, P., C. Saillard, and J. M. Bové. 1983. DNA extraction and purification. Methods Mycoplasmol. 1:295-299.

9. Carle, P., C. Saillard, and J. M. Bové. 1983. Determination of guanine plus cytosine content of DNA. Methods Mycoplasmol. 1:301-308.

10. Chastel, C., and I. Humphrey-Smith. 1991. Mosquito spiroplasmas, p. 149-206. In K. F. Harris (ed.), Advances in disease vector research, vol. 7. Springer-Verlag, New York.

11. Clark, T. B. 1983. Spiroplasmas: diversity of arthropod reservoirs and host-parasite relationships. Science 217:57-59.

12. Clark, T. B., R. F. Whitcomb, J. G. Tully, C. Mouches, C. Saillard, J. M. Bové, H. Wróblewski, P. Carle, D. L. Rose, R. B. Henegar, and D. L. Williamson. 1985. Spiroplasma melliferum, a new species from the honeybee (Apis mellifera). Int. J. Syst. Bacteriol. 35:296-308.

13. Clyde, W. A., Jr. 1983. Growth inhibition tests. Methods Mycoplasmol. 1:405-410.

14. Easton, E. R., J. E. Keirans, R. A. Gresbrink, and C. M. Clifford. 1977. The distribution in Oregon of Ixodes pacificus, Dermacentor andersoni, and Dermacentor occidentalis, with a note on Dermacentor variabilis (Acarina: Ixodidae). J. Med. Entomol. 13:501-506.

15. French, F. E., R. F. Whitcomb, J. G. Tully, K. J. Hackett, E. A. Clark, R. B. Henegar, A. G. Wagner, and D. L. Rose. 1990. Tabanid spiroplasmas of the southeast USA: new groups, and correlation with host life history strategy. Zentralbl. Bakteriol. Suppl. 20:919-921.

16. Freundt, E. A., B. E. Andrews, H. Ernø, M. Kunze, and F. T. Black. 1973. The sensitivity of Mycoplasmatales to sodium-polyanethol-sulfonate and digitonin. Zentralbl. Bakteriol. Parasitenkd. Infektionskr. Hyg. 225:104-112.

17. Gardella, R. S., and R. A. Del Giudice. 1983. Hemagglutination, hemadsorption, and hemolysis. Methods Mycoplasmol. 1:379-384.

18. Gasparich, G. E., C. Saillard, E. A. Clark, M. Konai, F. E. French, J. G. Tully, K. J. Hackett, and R. F. Whitcomb. 1993. Serologic and genomic relatedness of group VIII and group XVII spiroplasmas and subdivision of spiroplasma group VIII into subgroups. Int. J. Syst. Bacteriol. 43:338-341.

19. Hackett, K. J., and T. B. Clark. 1989. Ecology of spiroplasmas, p. 113-200. In R. F. Whitcomb and J. G. Tully (ed.), The mycoplasmas, vol. 5. Academic Press, New York.

20. International Committee on Systematic Bacteriology Subcommittee on the Taxonomy of Mollicutes. 1979. Proposal of minimal standards for descriptions of new species of the class Mollicutes. Int. J. Syst. Bacteriol. 29:172-180.

21. Junca, P., C. Saillard, J. G. Tully, O. Garcia-Jurado, J. R. Degorce-Dumas, 
C. Mouches, J. C. Vignault, R. Vogel, R. McCoy, R. F. Whitcomb, D. L. Williamson, J. Latrille, and J. M. Bové. 1980. Charactérisation de spiroplasmas isolés d'insectes et de fleurs de France continentale, de Corse et du Maroc. Proposition pour classification des spiroplasmas. C. R. Acad. Sci. Ser. D 290:1209-1212.

22. Manweiler, S. A., R. S. Lane, W. M. Block, and M. L. Morrison. 1990. Survey of birds and lizards for ixodid tick (Acari) and spirochetal infection in northern California. J. Med. Entomol. 27:1011-1015.

23. Manweiler, S. A., R. S. Lane, and C. H. Tempelis. 1992. The western fence lizard Sceloporus occidentalis: evidence of field exposure to Borrelia burgdorferi in relation to infestation by Ixodes pacificus (Acari: Ixodidae). Am. J. Trop. Med. Hyg. 47:328-336.

24. Mouches, C., J. M. Bové, J. G. Tully, D. L. Rose, R. E. McCoy, P. Carle-Junca, M. Garnier, and C. Saillard. 1983. Spiroplasma apis, a new species from the honeybee (Apis mellifera). Ann. Microbiol. 134:383-397.

25. Pyle, L. E., L. N. Corcoran, B. G. Cocks, A. D. Bergemann, J. C. Whitley, and L. R. Finch. 1988. Pulsed-field electrophoresis indicates larger-than-expected sizes for mycoplasma genomes. Nucleic Acids Res. 16:6015-6025.

26. Razin, S., and J. G. Tully. 1970. Cholesterol requirement of mycoplasmas. J Bacteriol. 102:306-310.

27. Rose, D. L., J. G. Tully, J. M. Bové, and R. F. Whitcomb. 1993. A test for measuring growth responses of mollicutes to serum and polyoxyethylene sorbitan. Int. J. Syst. Bacteriol. 43:527-532.

28. Rose, D. L., J. G. Tully, R. F. Whitcomb, D. L. Williamson, and J. M. Bové. 1983. Unique characteristics of the Y32 group of spiroplasmas (group VI) recovered from Lxodes pacificus ticks. Yale J. Biol. Med. 56:844-845.

29. Saglio, P., M. Lhospital, D. Laflèche, G. Dupont, J. M. Bové, J. G. Tully, and E. A. Freundt. 1973. Spiroplasma citri gen. and sp. n.: a mycoplasma-like organism associated with "stubborn" disease of citrus. Int. J. Syst. Bacteriol. 23:191-204.

30. Saillard, C., J. C. Vignault, J. M. Bové, A. Raie, J. G. Tully, D. L. Williamson, A. Fos, M. Garnier, A. Gadeau, P. Carle, and R. F. Whitcomb. 1987. Spiroplasma phoeniceum sp. nov., a new plant-pathogenic species from Syria. Int. J. Syst. Bacteriol. 37:106-115.

31. Senterfit, L. B. 1983. Preparation of antigens and antisera. Methods Mycoplasmol. 1:401-404.

32. Tully, J. G. 1983. Reflections on recovery of some fastidious mollicutes with implications of the changing host patterns of these organisms. Yale J. Biol. Med. 56:799-813.

33. Tully, J. G. 1983. Cloning and filtration techniques for mycoplasmas. Methods Mycoplasmol. 1:173-177.

34. Tully, J. G. 1983. Tests for digitonin sensitivity and sterol requirement. Methods Mycoplasmol. 1:355-362.

35. Tully, J. G., J. M. Bové, F. Laigret, and R. F. Whitcomb. 1993. Revised taxonomy of the class Mollicutes: proposed elevation of a monophyletic cluster of arthropod-associated mollicutes to ordinal rank (Entomoplasmatales ord. nov.), with provision for familial rank to separate species with nonhelical morphology (Entomoplasmataceae fam. nov.) from helical species (Spiroplasmataceae), and emended descriptions of the order Mycoplasmatales, family Mycoplasmataceae. Int. J. Syst. Bacteriol. 43:378-385.

36. Tully, J. G., D. L. Rose, E. Clark, P. Carle, J. M. Bové, R. B. Henegar, R. F. Whitcomb, D. E. Colflesh, and D. L. Williamson. 1987. Revised group classification of the genus Spiroplasma (class Mollicutes), with proposed new groups XII to XXIII. Int. J. Syst. Bacteriol. 37:357-364.

37. Tully, J. G., D. L. Rose, C. E. Yunker, J. Cory, R. F. Whitcomb, and D. L. Williamson. 1981. Helical mycoplasmas (spiroplasmas) from Ixodes ticks. Science 212:1043-1045.

38. Tully, J. G., and R. F. Whitcomb. 1991. The genus Spiroplasma, p. 19601980. In A. Balows, H. G. Trüper, M. Dworkin, W. Harder, and K.-H. Schleifer (ed.), The prokaryotes, vol. 2, 2nd ed. Springer-Verlag, New York.

39. Tully, J. G., R. F. Whitcomb, D. L. Rose, and J. M. Bové. 1982. Spiroplasma mirum, a new species from the rabbit tick (Haemaphysalis leporispalustris). Int. J. Syst. Bacteriol. 32:92-100.

40. Tully, J. G., R. F. Whitcomb, D. L. Rose, D. L. Williamson, and J. M. Bové. 1983. Characterization and taxonomic status of tick spiroplasmas: a review. Yale J. Biol. Med. 56:599-603.

41. Tully, J. G., R. F. Whitcomb, D. L. Williamson, and H. F. Clark. 1976. Suckling mouse cataract agent is a helical wall-free prokaryote (spiroplasma) pathogenic for vertebrates. Nature (London) 259:117-120.

42. Weisburg, W. G., J. G. Tully, D. L. Rose, J. P. Petzel, H. Oyaizu, D. Yang, L. Mandelco, J. Sechrest, T. G. Lawrence, J. Van Etten, J. Maniloff, and C. R. Woese. 1989. A phylogenetic analysis of the mycoplasmas: basis for their classification. J. Bacteriol. 171:6455-6467.

43. Whitcomb, R. F. 1983. Culture media for spiroplasmas. Methods Mycoplasmol. 1:147-158.

44. Whitcomb, R. F., J. M. Bové, T. A. Chen, J. G. Tully, and D. L. Williamson. 1987. Proposed criteria for an interim serogroup classification for members of the genus Spiroplasma (class Mollicutes). Int. J. Syst. Bacteriol. 37:82-84.

45. Whitcomb, R. F., K. J. Hackett, J. G. Tully, E. A. Clark, F. E. French, R. B. Henegar, D. L. Rose, and A. Wagner. 1990. Tabanid spiroplasmas as a model for mollicute biogeography. Zentralbl. Hyg. Suppl. 20:931-933.

46. Whitcomb, R. F., and J. G. Tully. 1984. Family III. Spiroplasmataceae Skripal 1983, 408. genus I. Spiroplasma, p. 781-787. In N. R. Krieg and J. G. Holt (ed.), Bergey's manual of systematic bacteriology, vol. 1. Williams and Wilkins, Baltimore.

47. Whitcomb, R. F., J. G. Tully, P. McCawley, and D. L. Rose. 1982. Application of the growth inhibition test to Spiroplasma taxonomy. Int. J. Syst. Bacteriol. 32:387-394.

48. Whitcomb, R. F., J. G. Tully, D. L. Williamson, J. M. Bové, F. E. French, M. Konai, G. Gasparich, M. Abalain-Colloc, C. Saillard, C. Chastel, P. Carle, D. L. Rose, R. Henegar, E. A. Clark, and K. J. Hackett. 1992. Revised classification of spiroplasmas. IOM Lett. 2:134.

49. Williamson, D. L., and J. G. Tully. 1983. Guinea pig complement inhibits growth of Ixodes tick-derived Y32 spiroplasmas. Yale J. Biol. Med. 56:845846.

50. Williamson, D. L., J. G. Tully, and R. F. Whitcomb. 1979. Serological relationships of spiroplasmas as shown by combined deformation and inhibition tests. Int. J. Syst. Bacteriol. 29:345-351.

51. Williamson, D. L., J. G. Tully, and R. F. Whitcomb. 1989. The genus Spiroplasma, p. 71-111. In R. F. Whitcomb and J. G. Tully (ed.), The mycoplasmas, vol. 5. Academic Press, New York.

52. Williamson, D. L., R. F. Whitcomb, and J. G. Tully. 1978. The spiroplasma deformation test, a new serological method. Curr. Microbiol. 1:203-207.

53. Yunker, C. E., J. G. Tully, and J. Cory. 1987. Arthropod cell lines in the isolation and propagation of tickborne spiroplasmas. Curr. Microbiol. 15: 45-50. 